Article

\title{
Inhibition and Interactions of Campylobacter jejuni from Broiler Chicken Houses with Organic Acids
}

\author{
Ross C. Beier*®D, J. Allen Byrd ${ }^{\oplus}$, Denise Caldwell, Kathleen Andrews, Tawni L. Crippen ${ }^{\circledR}$, \\ Robin C. Anderson 1 and David J. Nisbet $(\mathbb{D}$ \\ United States Department of Agriculture, Agricultural Research Service, Southern Plains Agricultural Research \\ Center, Food and Feed Safety Research Unit, College Station, TX 77845-4988, USA \\ * Correspondence: ross.beier@usda.gov
}

Received: 18 June 2019; Accepted: 27 July 2019; Published: 30 July 2019

check for updates

\begin{abstract}
Campylobacter jejuni is a bacterium that causes major diarrheal disease worldwide and is also one of the top five foodborne pathogens encountered in the United States. Poultry is a major source of C. jejuni, and a high-risk factor for contracting campylobacteriosis. Organic acids are used in the United States during food animal processing for removal of bacterial contamination from animal carcasses. Six organic acids were evaluated in inhibition studies of 96 C. jejuni strains obtained from shoe covers used in broiler chicken houses at different poultry farms in several states by determining the susceptibilities of the $C$. jejuni strains, along with the $\mathrm{pH}$ values at the molar minimum inhibitory concentrations $\left(\mathrm{MIC}_{\mathrm{M}} \mathrm{s}\right)$. The undissociated and dissociated organic acid concentrations were calculated at the $\mathrm{MIC}_{\mathrm{M}} \mathrm{s}$ with the Henderson-Hasselbalch equation. The results for the $96 \mathrm{C}$. jejuni strains were treated similarly for each different organic acid. Campylobacter jejuni inhibition did correlate with the dissociated organic acids, but did not correlate with $\mathrm{pH}$ or with the undissociated organic acids. When the concentrations of dissociated organic acids decreased, the C. jejuni strains were not disinfected. A carcass wash using organic acids should have the concentration of dissociated acid species carefully controlled. It is suggested to maintain a dissociated acid concentration for propionic, L-lactic, formic, citric, butyric, and acetic acids at $24,40,36,21,23$, and $25 \mathrm{mM}$, respectively, and at these dissociated organic acid levels an acid wash would be expected to remove or inhibit $97 \%$ or more of the $C$. jejuni bacteria studied here. However, studies must be undertaken to confirm that the suggested concentrations of dissociated organic acids are adequate to remove $C$. jejuni bacteria in the field vs. the laboratory. Due to propionate, L-lactate, formate, butyrate, and acetate being utilized by C. jejuni, these organic acids may not be appropriate for use as a carcass wash to remove C. jejuni surface contamination. Of all tested organic acids, dissociated citric acid was the most efficient at inhibiting C. jejuni.
\end{abstract}

Keywords: acetic acid; Campylobacter jejuni; citric acid; formic acid; L-lactic acid; molar minimum inhibitory concentrations $\left(\mathrm{MIC}_{\mathrm{M}} \mathrm{s}\right)$; organic acids; propionic acid; broiler chickens; susceptibility

\section{Introduction}

Campylobacter jejuni is a bacterial organism that causes gastroenteritis worldwide [1-6]. Campylobacter jejuni are Gram-negative bacteria that are non-spore-forming [7] and are known to be a major cause of diarrheal disease in humans [8]. Campylobacter species are within the top five of the 31 major foodborne pathogens in the United States, and the Centers for Disease Control and Prevention (CDC) has estimated that each year, Campylobacter species cause 845,024 illnesses, 8,463 hospitalizations, and 76 deaths in the U.S. [9,10]. The two main Campylobacter species usually associated with human foodborne illnesses worldwide are C. jejuni and C. coli [2,11-13]. These two bacteria have high DNA homology [14], with related or identical antigens [15]. The most bacterial foodborne illnesses in the 
United States in 2016 were a result of Campylobacter and Salmonella, as described by the CDC [16]. However, most human Campylobacter infections are caused by $C$. jejuni $[2,4,8,17]$. Poultry have been found to be a major source of $C$. jejuni exposure, and consuming poultry food products is recognized as a high-risk factor for contracting campylobacteriosis [18-23]. Campylobacter infections may be fatal among young children, the elderly, and immunosuppressed patients (HIV patients) [6,24]. In particular, the incidence of Campylobacter infections in children $<2$ years of age in Israel has increased over the last few years to become the highest among industrialized countries [23]. A C. jejuni infective dose of only about $500-800$ bacteria are required for infection $[25,26]$.

New strategies to control animal-derived foodborne pathogens from the farm-to-fork must be developed to prevent illness due to these pathogens [27]. An important step used in the United States in the meat processing plant is a surface animal carcass wash containing organic acids (OAs) to remove bacterial contamination. Some short-chain OAs have been used to remove $C$. jejuni from avian carcasses in poultry processing plants [28-31], and studies using OAs have been conducted to remove or reduce C. jejuni populations in live birds during grow-out and preslaughter feed withdrawal [31-36]. The remaining bacteria found on carcasses in processing plants may later proliferate and be found on the processed meat, and meat marination studies have also been conducted using OAs to remove foodborne pathogens on the resulting processed chicken meat [37].

The mechanism of OA bacterial inhibition has been traditionally assumed to be mainly dependent on $\mathrm{pH}$ [38] or the undissociated form of the OAs [39-44], which are thought to penetrate the lipid membrane. However, the specific mechanism(s) by which OAs inhibit bacteria are not known [38,45-47]. In previous studies designed to evaluate foodborne pathogen interactions with OAs, molar units for concentration were used for the minimum inhibitory concentrations $\left(\mathrm{MIC}_{\mathrm{M}} \mathrm{s}\right)$ of the OAs when comparing $\mathrm{pH}$, and undissociated and dissociated $\mathrm{OA}$ data, because it results in an accurate analysis between MIC results of OAs with different molecular weights [48]. Our previous studies evaluated Escherichia coli O157:H7 [48], non-O157 Shiga toxin-producing E. coli (non-O157 STECs) [49], Salmonella enterica serovars [50], vancomycin-resistant Enterococcus faecium (VRE) [51], and C. coli [52] against OAs. These studies against OAs showed no correlation between $\mathrm{pH}$ or the undissociated OAs and bacterial $\mathrm{MIC}_{\mathrm{M}} \mathrm{s}$. However, the dissociated OAs did show a close correlation with the $\mathrm{MIC}_{\mathrm{M}} \mathrm{s}$, and the disintegration of a bacterial LPS layer has been demonstrated by a dissociated OA [53]. It was observed in previous research that bacteria would be expected to escape disinfection if the concentration of the dissociated OAs decreased below optimum levels [48-52].

Here, we studied the interactions of 96 C. jejuni strains isolated from shoe covers used in broiler chicken houses at different poultry farms in several different states with a number of OAs. Susceptibility studies were conducted with the 96 C. jejuni strains against the OAs, propionic, L-lactic, formic, citric, butyric, and acetic acid, and the $\mathrm{pH}$ was determined at the MICs. Calculations of the concentrations of undissociated and dissociated $\mathrm{OAs}$ at the $\mathrm{MIC}_{\mathrm{M}}$ s were undertaken. The $\mathrm{pH}$ and concentrations of the undissociated and dissociated $\mathrm{OA}$ species are compared at the $\mathrm{MIC}_{\mathrm{M}} \mathrm{s}$ for all $C$. jejuni strains and show a good association between the dissociated OA species and bacterial inhibition.

\section{Materials and Methods}

\subsection{Campylobacter jejuni}

Campylobacter jejuni strains $(n=96)$ were isolated from broiler chicken houses at different poultry farms in several different states. Two shoe covers (97041-234, VWR, Missouri City, TX, USA) were placed into an autoclavable plastic container with $100 \mathrm{~mL}$ of $2 \times$ skim milk (232100, Difco ${ }^{\mathrm{TM}}$, Becton, Dickinson and Company, Sparks, MD, USA) and autoclaved for $15 \mathrm{~min}$ at $121^{\circ} \mathrm{C}$. Four pairs of shoe covers were used for each chicken house. The shoe covers were placed over boots and used as swabs to collect bacteria from the litter on the chicken house floor. The shoe covers were worn while walking $\frac{1}{2}$ the length of the house on one side, and then they were removed and replaced with two fresh shoe covers. When reaching the end of the house, this process was repeated for the walk 
back to the front of the house. The four pairs of exposed shoe covers were packed in an ice chest and shipped to the laboratory. After arrival at the laboratory, $90 \mathrm{~mL}$ of buffered peptone water (212367, BBL $^{\mathrm{TM}}$, Becton, Dickinson and Company, Sparks, MD, USA) was added to each pair of shoe covers and shaken. Samples were subjected to direct plating (one plate directly from each sample) and one from a 1:10 peptone water dilution (for a total of two plates) for enumeration on Campy-cefex agar (C-C) plates [54], and were incubated at $42{ }^{\circ} \mathrm{C}$ in a microaerobic environment $\left(5 \% \mathrm{O}_{2}, 10 \% \mathrm{CO}_{2}, 85 \%\right.$ $\mathrm{N}_{2}$ ) for $48 \mathrm{~h}$. Additionally, $5 \mathrm{~mL}$ of each peptone water sample was added to $5 \mathrm{~mL}$ of $2 \times$ Bolton enrichment broth [54] and incubated at $42{ }^{\circ} \mathrm{C}$ overnight. The samples were then plated onto C-C plates and incubated at $42{ }^{\circ} \mathrm{C}$ in the microaerobic environment for $48 \mathrm{~h}$. Five colonies from each positive C-C plate were isolated and placed on trypticase soy agar w/5\% sheep blood BD BBL ${ }^{\mathrm{TM}}$ Stacker ${ }^{\mathrm{TM}}$ (TSA) plates (\#221261, Becton, Dickinson and Company, Sparks, MD, USA) in an anaerobic chamber (5\% $\mathrm{H}_{2}, 5 \% \mathrm{CO}_{2}, 90 \% \mathrm{~N}_{2}$ ), and then transferred to Brucella Broth (211088, BBL ${ }^{\mathrm{TM}}$, Becton, Dickinson and Company, Sparks, MD, USA) containing 20\% glycerol (GX0185-5, EM Science, Gibbstown, NJ, USA) and placed at $-80^{\circ} \mathrm{C}$ for storage. Samples were also sent to the National Antimicrobial Resistance Monitoring System (NARMS) for Sensititre ${ }^{\mathrm{TM}}$ antimicrobial susceptibility testing.

\subsection{Susceptibility Testing of $\mathrm{C}$. jejuni Strains with Organic Acids}

The C. jejuni OA MICs were obtained by using broth microdilution testing for fastidious bacteria, as described by the Clinical and Laboratory Standards Institute (CLSI) [55] and the TREK Diagnostic Systems published method for determining susceptibility using Campylobacter sensititre plates [56]. The susceptibility studies carried out here required Campylobacter incubation at $42{ }^{\circ} \mathrm{C}$ for $48 \mathrm{~h}$ because some strains did not sufficiently grow in $24 \mathrm{~h}$, as was also observed in an earlier Campylobacter coli study [52]. Briefly, $50 \mu \mathrm{L}$ of cation-adjusted Mueller-Hinton broth w/TES w/Lysed horse blood (Remel, Lenexa, KS, USA) was added to wells 2-12 of a 96-well U-bottom Greiner bio-one microplate (\#650161, VWR International, LLC, Bridgeport, NJ, USA), and $50 \mu \mathrm{L}$ of each standard OA solution was added to wells 1 and 2, and the solution in well 2 was further diluted 1:2 across the microplate through column 11, and the wells in column 12 were the positive controls [52]. Campylobacter jejuni colonies were then selected from TSA plates, and diluted into tubes containing $5 \mathrm{~mL}$ cation-adjusted Mueller-Hinton broth w/TES (Remel, Lenexa, KS, USA) to be equivalent to a 0.5 McFarland standard using a TREK Diagnostic Systems Nephelometer (East Grinsted, UK). Because the wells in the organic acid susceptibility plates contain a final volume of $100 \mu \mathrm{L}, 200 \mu \mathrm{L}$ of the $0.5 \mathrm{McF}$ arland suspension was then added to tubes that contained $11 \mathrm{~mL}$ Mueller-Hinton broth w/TES w/Lysed horse blood, resulting in $1 \times 10^{6} \mathrm{CFU} / \mathrm{mL}$ of each bacterial isolate, as previously described [52]. The horse blood bacterial solution ( $50 \mu \mathrm{L} /$ well) was added to each well of the 96-well plates. A perforated plastic adhesive cover sheet (YG522EA, Remel) was placed over the bacteria-loaded microplates, and the covered plates were placed in the BD GasPak $^{\mathrm{TM}}$ EZ incubation containers (Becton, Dickinson and Company, Sparks, MD, USA). Sachets (BD \#260680) were enclosed in the EZ containers according to the manufacturer's instructions, along with a $100 \mathrm{~mL}$ beaker half full of water to provide a moisturized atmosphere, and the containers were closed. This system provided a microaerobic atmosphere, where they were incubated for $48 \mathrm{~h}$ at $42{ }^{\circ} \mathrm{C}$. The microplate well containing the smallest OA concentration that had no visible bacterial growth was considered the minimum inhibitory concentration (MIC) [57], as observed on a SensiTouch imaging system (TREK Diagnostic Systems Ltd., East Grinsted, UK). Campylobacter jejuni ATCC 33560 was run along with each test as the control organism. The results obtained here for ATCC 33560 were compared with results obtained from testing these same OAs against the control organism Escherichia coli ATCC 25922 in aerobic conditions, as ATCC 25922 was used as the control organism during all previous aerobic OA susceptibility testing studies [48-51,58-61]. 
The concentrations of OAs tested were equivalent to those previously used against $C$. coli [49]: propionic acid, 32,768-32 $\mu \mathrm{g} / \mathrm{mL}$; formic acid, $16,384-16 \mu \mathrm{g} / \mathrm{mL}$; citric acid, $16,384-16 \mu \mathrm{g} / \mathrm{mL}$; butyric acid, 16,384-16 $\mu \mathrm{g} / \mathrm{mL}$; and acetic acid, 32,768-32 $\mu \mathrm{g} / \mathrm{mL}$; except for L-lactic acid, 16,384-16 $\mu \mathrm{g} / \mathrm{mL}$. Acetic acid was purchased from EM Science (Gibbstown, NY, USA). Citric, butyric, propionic, and formic acids were purchased from Sigma-Aldrich (Milwaukee, WI, USA). L-Lactic acid was purchased from Alfa Aesar (Wad Hill, MA, USA). Reverse osmosis water was used to dilute the OAs to make standard solutions, and they were filter-sterilized using a $0.2 \mu \mathrm{m} \times 25 \mathrm{~mm}$ syringe filter (\# 431224, Corning Inc., Corning, NY, USA).

\subsection{Determination of $\mathrm{pH}$ in Wells of the $96-$ Well Microplates at the C. jejuni MICs}

$\mathrm{pH}$ analysis was performed as previously described [52]. Briefly, the $\mathrm{pH}$ was determined of the solutions in the MIC wells for all OAs in triplicate, and the means and standard deviations were calculated. The solutions at the same MIC from 16-wells $(100 \mu \mathrm{L} /$ well) for each OA were added together (for a total of $1600 \mu \mathrm{L}$ ) in a $5 \mathrm{~mL}$ sterile microtube (Argos Technologies, Inc., Vernon Hills, IL, USA). An Orion benchtop $\mathrm{pH}$ meter with a ROSS Ultra glass combination $\mathrm{pH}$ electrode was used to determine the $\mathrm{pH}$ (Thermo Fisher Scientific, Chelmsford, MA, USA).

\subsection{The Calculated Ratio of Undissociated/Dissociated OAs}

It is well-known that when the $\mathrm{pH}$ and $\mathrm{pK}_{\mathrm{a}}$ are known, the ratio of the undissociated/dissociated weak organic acid concentration can be calculated using the Henderson-Hasselbalch equation [62]:

$$
\mathrm{pH}=\mathrm{pK}_{\mathrm{a}}+\log \left(\frac{\left[\mathrm{A}^{-}\right]}{[\mathrm{HA}]}\right)
$$

where $\mathrm{pK}_{\mathrm{a}}$ is equal to the $-\log _{10}$ of the organic acid dissociation constant $\left(\mathrm{K}_{\mathrm{a}}\right),\left[\mathrm{A}^{-}\right]$is the molar concentration of the conjugate base (dissociated organic acid), and [HA] is the molar concentration of the undissociated organic acid [62]. Rearrangement of the Henderson-Hasselbalch equation can provide the ratio of the undissociated/dissociated weak organic acid [40]:

$$
\text { ratio }=\frac{[\mathrm{HA}]}{\left[\mathrm{A}^{-}\right]}=\frac{1}{10^{\mathrm{pH}^{-} \mathrm{pK}_{\mathrm{a}}}}
$$

The ratio of the undissociated/dissociated acid can then be calculated using the published $\mathrm{pK}_{\mathrm{a}}$ of each OA and the results of the measured $\mathrm{pH}$ at the MICs. The $\mathrm{pK}_{\mathrm{a}}$ for propionic, $\mathrm{L}$-lactic, formic, citric, butyric, and acetic acid is $4.87,3.86,3.75,3.14,4.82$, and 4.75 , respectively. The $\mathrm{pH}$ was experimentally determined, the molar concentrations of the OAs are known at the bacterial MICs, and the molar concentrations of the undissociated and dissociated OA species at each MIC can then be calculated from the ratio obtained from the Henderson-Hasselbalch equation [48-52].

\subsection{Statistics}

The central tendency of the organic acid MICs and $\mathrm{MIC}_{\mathrm{M}} \mathrm{s}$ for the $96 \mathrm{C}$. jejuni strains isolated from chicken houses was defined by showing the 90th percentile, range, mode, and median of the data. The mean and standard deviation of triplicate $\mathrm{pH}$ samples at each MIC for each OA were calculated. 


\section{Results}

\subsection{Susceptibility Studies of OAs Against the C. jejuni strains}

Table 1 presents the MICs and $\mathrm{MIC}_{\mathrm{M}}$ s data determined for the 96 C. jejuni strains against all the OAs evaluated. L-Lactic and formic acid $\mathrm{MIC}_{\mathrm{M}}$ s demonstrated the greatest levels of OAs needed to inhibit all the C. jejuni strains tested (90.94 and $89.0 \mathrm{mM}$ ), respectively. The OA molar concentration required for inhibition of $C$. jejuni by these two acids was followed by the molar concentrations of acetic, propionic, and butyric acid of $68.21,55.29$, and $46.49 \mathrm{mM}$, respectively. The lowest molar concentration required to inhibit the $C$. jejuni strains was for citric acid $(21.32 \mathrm{mM})$. The $C$. jejuni citric acid $\mathrm{MIC}_{\mathrm{M}}$ concentrations were by far the lowest levels observed of all the OAs tested.

Table 1. The determined organic acid MICs and $\mathrm{MIC}_{\mathrm{MS}}{ }^{\text {a }}$ for 96 Campylobacter jejuni strains isolated from shoe covers worn in broiler chicken houses.

\begin{tabular}{|c|c|c|c|}
\hline Organic Acids & $\operatorname{MIC}(\mu \mathrm{g} / \mathrm{mL})$ & $\mathrm{MIC}_{\mathbf{M}}(\mathrm{mM})$ & No. of $C$. jejuni Strains \\
\hline \multirow{4}{*}{ Acetic Acid } & 4096 & 68.21 & 1 \\
\hline & 2048 & 34.10 & 13 \\
\hline & 1024 & 17.05 & 75 \\
\hline & 512 & 8.53 & 7 \\
\hline \multirow{5}{*}{ Butyric Acid } & 4096 & 46.49 & 3 \\
\hline & 2048 & 23.25 & 47 \\
\hline & 1024 & 11.62 & 40 \\
\hline & 512 & 5.81 & 5 \\
\hline & 256 & 2.91 & 1 \\
\hline \multirow{5}{*}{ Citric Acid } & 4096 & 21.32 & 1 \\
\hline & 2048 & 10.66 & 11 \\
\hline & 1024 & 5.33 & 74 \\
\hline & 512 & 2.67 & 9 \\
\hline & 256 & 1.33 & 1 \\
\hline \multirow{4}{*}{ Formic Acid } & 4096 & 89.00 & 1 \\
\hline & 2048 & 44.5 & 22 \\
\hline & 1024 & 22.25 & 63 \\
\hline & 512 & 11.12 & 10 \\
\hline \multirow{6}{*}{ L-Lactic Acid } & 8192 & 90.94 & 3 \\
\hline & 4096 & 45.47 & 14 \\
\hline & 2048 & 22.74 & 44 \\
\hline & 1024 & 11.37 & 30 \\
\hline & 512 & 5.68 & 4 \\
\hline & 256 & 2.84 & 1 \\
\hline \multirow{7}{*}{ Propionic Acid } & 4096 & 55.29 & 1 \\
\hline & 2048 & 27.65 & 5 \\
\hline & 1024 & 13.82 & 17 \\
\hline & 512 & 6.91 & 25 \\
\hline & 256 & 3.46 & 30 \\
\hline & 128 & 1.73 & 14 \\
\hline & 64 & 0.86 & 4 \\
\hline
\end{tabular}

${ }^{\mathrm{a}} \mathrm{MIC}_{\mathrm{M}} \mathrm{s}=$ Molar MICs; MIC, minimum inhibitory concentration. 
The central tendency of the MIC data is shown in Table 2. The central tendency is a typical value found for a probability distribution. The highest median values are for L-lactic acid, formic acid, and butyric acid of 22.74, 22.25, and $23.24 \mathrm{mM}$, respectively, while the highest range values are for L-lactic acid, formic acid, acetic acid, and propionic acid of $90.94,89.00,68.21$, and $55.29 \mathrm{mM}$, respectively, and the 90th percentile follows the highest range values for L-lactic, formic, and acetic acid of 45.47, 44.50, and $34.10 \mathrm{mM}$, respectively, except for butyric and propionic acid of 23.25 and $13.82 \mathrm{mM}$, respectively.

Table 2. The central tendency of organic acid MICs and $\mathrm{MIC}_{\mathrm{MS}}{ }^{\text {a }}$ for 96 Campylobacter jejuni strains isolated from shoe covers worn in broiler chicken houses.

\begin{tabular}{|c|c|c|c|c|}
\hline Organic Acid & Median & Mode & Range & 90th Percentile \\
\hline \multicolumn{5}{|l|}{ Acetic Acid } \\
\hline $\operatorname{MIC}(\mu \mathrm{g} / \mathrm{mL})$ & 1024 & 1024 & $512-4096$ & 2048 \\
\hline $\mathrm{MIC}_{\mathrm{M}}(\mathrm{mM})$ & 17.05 & 17.05 & $8.53-68.21$ & 34.1 \\
\hline \multicolumn{5}{|l|}{ Butyric Acid } \\
\hline $\mathrm{MIC}(\mu \mathrm{g} / \mathrm{mL})$ & 2048 & 2048 & $256-4096$ & 2048 \\
\hline $\mathrm{MIC}_{\mathrm{M}}(\mathrm{mM})$ & 23.24 & 23.25 & $2.91-46.49$ & 23.25 \\
\hline \multicolumn{5}{|l|}{ Citric Acid } \\
\hline $\mathrm{MIC}(\mu \mathrm{g} / \mathrm{mL})$ & 1024 & 1024 & $256-4096$ & 2048 \\
\hline $\mathrm{MIC}_{\mathrm{M}}(\mathrm{mM})$ & 5.33 & 5.33 & $1.33-21.32$ & 10.66 \\
\hline \multicolumn{5}{|l|}{ Formic Acid } \\
\hline $\operatorname{MIC}(\mu \mathrm{g} / \mathrm{mL})$ & 1024 & 1024 & $512-4096$ & 2048 \\
\hline $\mathrm{MIC}_{\mathrm{M}}(\mathrm{mM})$ & 22.25 & 22.25 & $11.12-89.00$ & 44.5 \\
\hline \multicolumn{5}{|l|}{ L-Lactic Acid } \\
\hline $\mathrm{MIC}(\mu \mathrm{g} / \mathrm{mL})$ & 2048 & 2048 & $256-8192$ & 4096 \\
\hline $\mathrm{MIC}_{\mathrm{M}}(\mathrm{mM})$ & 22.74 & 22.74 & $2.84-90.94$ & 45.47 \\
\hline \multicolumn{5}{|l|}{ Propionic Acid } \\
\hline $\operatorname{MIC}(\mu \mathrm{g} / \mathrm{mL})$ & 256 & 256 & $64-4096$ & 1024 \\
\hline $\mathrm{MIC}_{\mathrm{M}}(\mathrm{mM})$ & 3.46 & 3.46 & $0.86-55.29$ & 13.82 \\
\hline
\end{tabular}

\subsection{Experimentally Determined $p H$ at the C. jejuni MICs for the 96 Strains Evaluated with the OAs}

The 96 C. jejuni strains were grouped together as one group for each OA; therefore, the six OAs resulted in six OA groups, each containing 96 strains. The experimentally determined $\mathrm{pH}$ values of the 96-well plates at the C. jejuni $\mathrm{MIC}_{\mathrm{M}} \mathrm{s}$ are shown in a graphical presentation in Figure 1. Triplicate samples were evaluated at each $\mathrm{pH}$ data point, and the number of strains at each $\mathrm{MIC}_{\mathrm{M}}$ is depicted next to each data point. The $\mathrm{pH}$ necessary to inhibit $100 \%$ of the strains with butyric acid was 5.14 , and that for $99 \%$ of the strains with propionic, citric, and acetic acid was 5.74, 5.58, and 5.18, respectively. However, the $\mathrm{MIC}_{\mathrm{M}} \mathrm{pH}$ for $99 \%$ of the bacterial strains evaluated with formic acid and $97 \%$ of the strains against $\mathrm{L}$-lactic acid was 4.4 and 4.39 , respectively. The $\mathrm{pH}$ value needed for inhibition of 97-100\% of $C$. jejuni against the six OAs falls into two different $\mathrm{pH}$ groupings, which has, on average, $1.01 \mathrm{pH}$ unit difference. The $\mathrm{pH}$ at $100 \%$ inhibition of the $C$. jejuni strains against formic acid and L-lactic acid is 3.71 and 3.74, respectively. Using these values, the $\mathrm{pH}$ difference for the two groupings with $100 \%$ of the strains being inhibited by formic acid and L-lactic acid is, on average, $1.69 \mathrm{pH}$ units. 


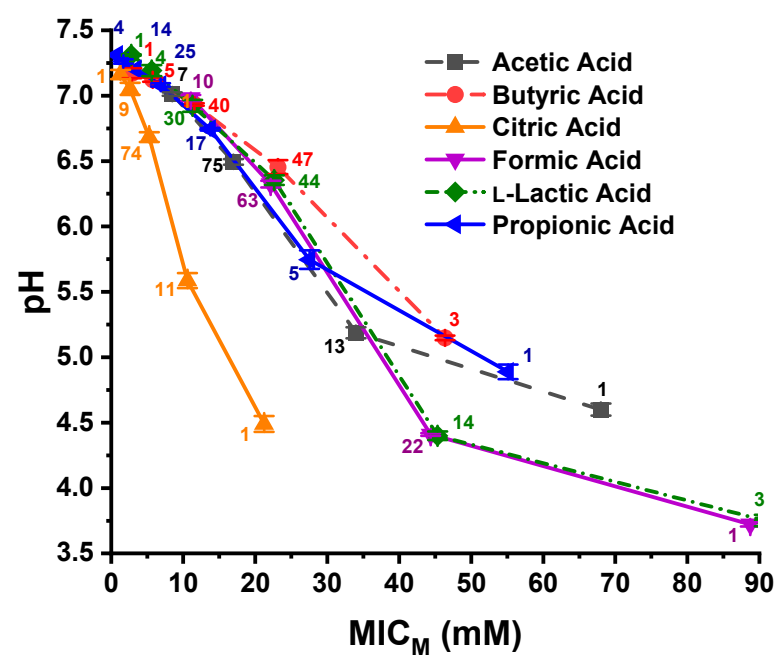

Figure 1. Presentation of $\mathrm{pH}$ at the $\mathrm{MIC}_{\mathrm{M}} \mathrm{s}$ of propionic, L-lactic, formic, citric, butyric, and acetic acids for 96 C. jejuni strains. The number of strains is displayed adjacent to the data points. The $\mathrm{pH}$ data points represent the mean and standard deviation of triplicate samples.

\subsection{Calculated Undissociated $O A$ Concentrations at the C. jejuni $M I C_{M S}$}

The undissociated OA concentrations of propionic, L-lactic, formic, citric, butyric, and acetic acids calculated using the Henderson-Hasselbalch equation at the $\mathrm{MIC}_{\mathrm{M}} \mathrm{s}$ of the $96 \mathrm{C}$. jejuni strains are shown in Figure 2. The undissociated L-lactic, formic, acetic, propionic, and butyric acid levels at the $\mathrm{MIC}_{\mathrm{M}}$ of $100 \%$ of the C. jejuni strains tested was $51.71,46.54,40.31,27.33$, and $15.05 \mathrm{mM}$, respectively, while the undissociated citric acid concentration of all $96 \mathrm{C}$. jejuni strains at their $\mathrm{MIC}_{\mathrm{M}} \mathrm{s}$ was only $0.932 \mathrm{mM}$. A difference of $\Delta=50.78 \mathrm{mM}$ OA between the $\mathrm{MIC}_{\mathrm{M}}$ of all 96 strains against L-lactic acid and citric acid are as shown by the large shaded area in Figure 2 .

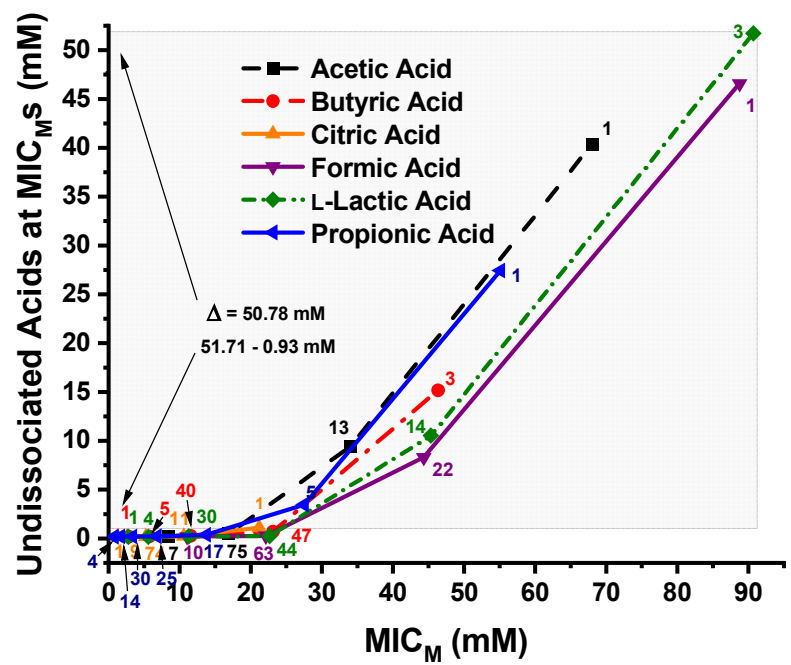

Figure 2. Concentrations (mM) of the six undissociated organic acids-propionic, L-lactic, formic, citric, butyricand acetic - at the $\mathrm{MIC}_{\mathrm{M}}$ s of the $96 \mathrm{C}$. jejuni strains. The large shaded area shows the difference between the undissociated L-lactic acid and citric acid levels required for disinfection of all 96 strains by all organic acids tested; $\Delta=50.78 \mathrm{mM}$. The number of strains is displayed next to each $\mathrm{MIC}_{\mathrm{M}}$ data point. 
Figure 3 shows the $\mathrm{pH}$ vs. undissociated OA concentrations at the $\mathrm{MIC}_{\mathrm{M}} \mathrm{s}$ of the six OAs against the 96 C. jejuni strains. The number of $C$. jejuni strains at the $\mathrm{MIC}_{\mathrm{M}}$ is displayed adjacent to each data point. Most of the $C$. jejuni strains were inhibited by undissociated OAs at concentrations approaching zero. The difference in the points where both citric acid and L-lactic acid inhibit $100 \%$ of the strains is approximately $51 \mathrm{mM}$ undissociated $\mathrm{OA}$ and a $\Delta \mathrm{pH}=0.74$ unit. At the points where $97 \%$ of the strains were inhibited by undissociated butyric acid and all 96 strains were inhibited by undissociated citric acid, the undissociated OA concentrations approach zero and the $\Delta \mathrm{pH}=1.97$ unit. At the points where $99 \%$ of the strains were inhibited by undissociated acetic acid and propionic acid, there is approximately a $5 \mathrm{mM}$ difference in undissociated OA concentrations and the $\Delta \mathrm{pH}=0.56$ unit.

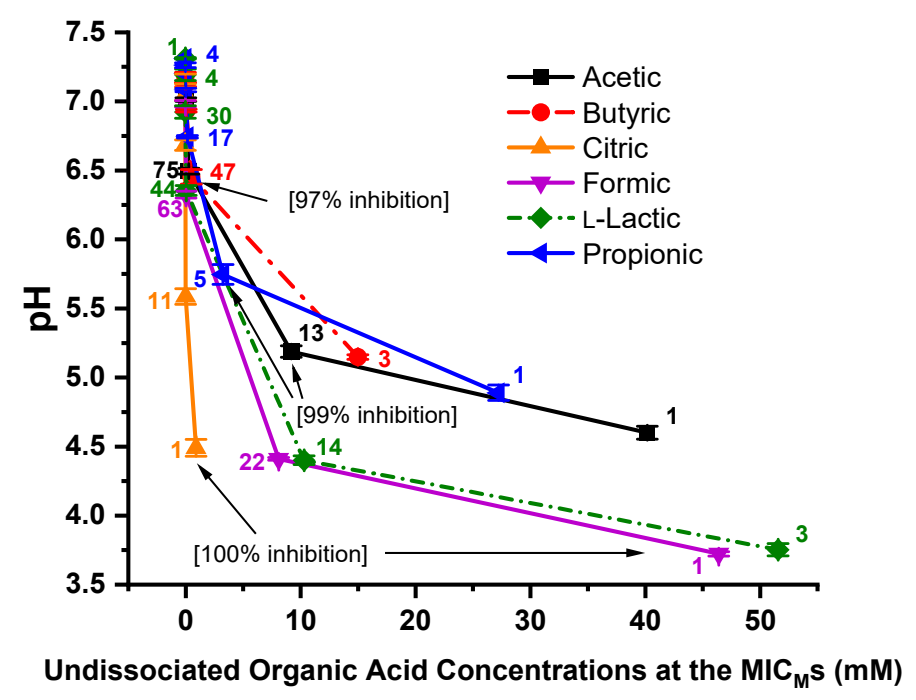

Figure 3. Plot of $\mathrm{pH}$ vs. $\mathrm{MIC}_{\mathrm{M}}$ s of the 96 Campylobacter jejuni strains against the six undissociated organic acids, propionic, L-lactic, formic, citric, butyric, and acetic acids. The number of strains is displayed adjacent to the $\mathrm{MIC}_{\mathrm{M}}$ data points. Each $\mathrm{pH}$ data point is the mean and standard deviation from triplicate samples.

\subsection{Calculated Dissociated $O A$ Concentrations at the C. jejuni $M I C_{M^{S}}$}

The dissociated OA concentrations of propionic, L-lactic, formic, citric, butyric, and acetic acids calculated using the Henderson-Hasselbalch equation at the $\mathrm{MIC}_{\mathrm{M}} \mathrm{s}$ of the $96 \mathrm{C}$. jejuni strains are shown in Figure 4. The dissociated OA concentrations required to produce $\mathrm{MIC}_{\mathrm{M}} \mathrm{s}$ for all $96 \mathrm{C}$. jejuni strains by citric acid and $99 \%$ of the strains by propionic acid and acetic acid and $97 \%$ of the strains by butyric acid are shown by the narrow, darker-shaded band in Figure 4. This darker-shaded band shows a $\Delta=4.47 \mathrm{mM}$ difference between the $\mathrm{MIC}_{\mathrm{M}}$ of all $96 \mathrm{C}$. jejuni strains inhibited by citric acid, and $99 \%$ of the strains inhibited by acetic acid. The $\mathrm{MIC}_{\mathrm{M}}$ for all 96 strains occurred at a dissociated citric acid level of $20.39 \mathrm{mM}$, and the $\mathrm{MIC}_{\mathrm{M}}$ for 95 of 96 strains occurred at a dissociated citric acid concentration of $10.62 \mathrm{mM}$. The $\mathrm{MIC}_{\mathrm{M}}$ for $100 \%$ of the strains for all dissociated OAs occurred at a level of $42.46 \mathrm{mM}$ formate. However, only the results for citric acid are not affected by C. jejuni OA utilization.

The plot of $\mathrm{pH}$ vs. dissociated OA concentrations at the $C$. jejuni $\mathrm{MIC}_{\mathrm{M}} \mathrm{s}$ against the six OAs is shown in Figure 5. The number of strains is displayed adjacent to each data point. The narrow, light green vertical box $(20.39 \mathrm{mM})$ depicts the data point for bacterial inhibition of all 96 strains by dissociated citric acid. The larger, light blue vertical box (22.72 to $24.86 \mathrm{mM}$ dissociated OAs) encompasses the data points for bacterial inhibition of $97-99 \%$ of the $C$. jejuni strains by dissociated butyric, acetic, and propionic acid. The red box encompasses the data points for bacterial inhibition of $97-99 \%$ of the strains by L-lactic acid and formic acid. Each $\mathrm{pH}$ data point is the mean and standard deviation of triplicate samples. 


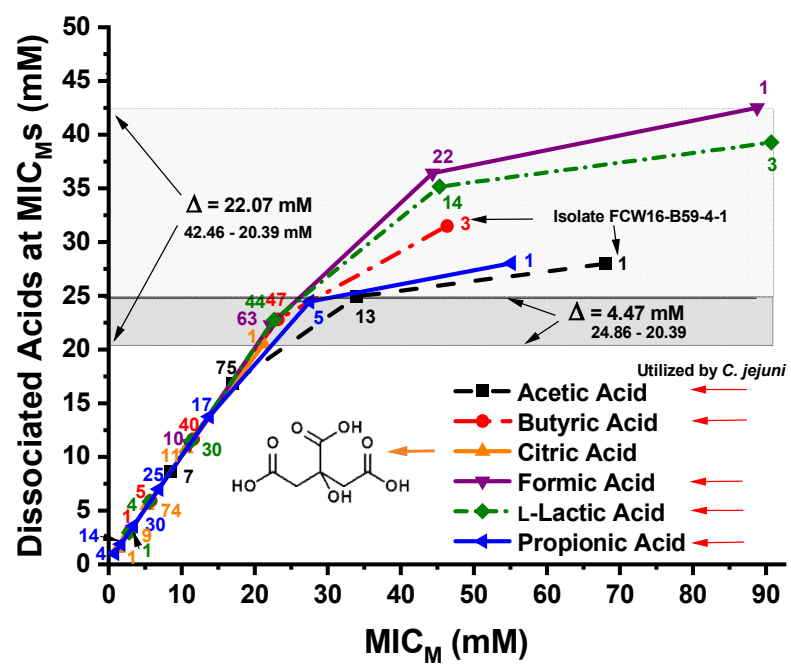

Figure 4. Concentrations (mM) of the six dissociated organic acids-propionic, L-lactic, formic, citric, butyric, and acetic - at the $\mathrm{MIC}_{\mathrm{M}} \mathrm{s}$ of the $96 \mathrm{C}$. jejuni strains. The larger, lightly shaded band shows the difference between dissociated citric acid and formic acid concentrations required for inhibition of $100 \%$ of the strains for all organic acids, $\Delta=22.07 \mathrm{mM}$, in excess of the level required for inhibition of all strains by citric acid. The line through the citric acid 1-strain (100\% of strains) and acetic acid 13-strains ( $99 \%$ of strains) $\mathrm{MIC}_{\mathrm{M}}$ data points are encompassed by the narrow dark band or difference in acid concentrations for inhibition of 100,97, 99, and 99\% of the C. jejuni strains by citric, butyric, acetic, and propionic acids, respectively, $\Delta=4.47 \mathrm{mM}$. The five arrows pointing toward the organic acids on the lower right of the figure are those OAs suggested in the literature as being utilized by $C$. jejuni. The number of strains is displayed adjacent to each $\mathrm{MIC}_{\mathrm{M}}$ data point.

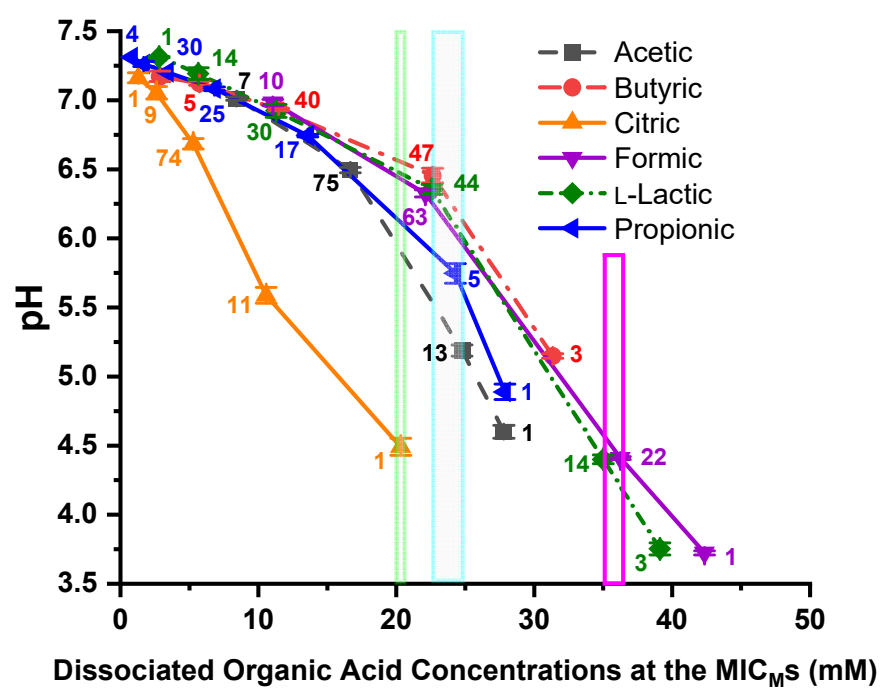

Figure 5. pH vs. $\mathrm{MIC}_{\mathrm{M}}$ of the 96 C. jejuni strains against the six dissociated organic acids-propionic, L-lactic, formic, citric, butyric, and acetic acid. The number of strains is displayed adjacent to each $\mathrm{MIC}_{\mathrm{M}}$ data point. The small, light green, vertical box at $20.39 \mathrm{mM}$ shows the inhibition of $100 \%$ of the strains by dissociated citric acid. The larger light blue vertical box ( 22.72 to $24.86 \mathrm{mM}$ ) encloses the inhibition of $97-99 \%$ of the C. jejuni strains by dissociated butyric, propionic, and acetic acid, $\Delta=2.14 \mathrm{mM}$. The magenta vertical box (35.11 to $36.36 \mathrm{mM}$ ) encloses the inhibition of $97-99 \%$ of the $C$. jejuni strains by dissociated L-lactic and propionic acid, $\Delta=1.25 \mathrm{mM}$. Each $\mathrm{pH}$ data point is the mean and standard deviation of triplicate samples. 


\section{Discussion}

Food processing plants often base pathogen decontamination strategies on $\mathrm{pH}[63,64]$. Organic acids are regularly used to remove foodborne bacteria from poultry carcasses in the United States [28-30]. However, many foodborne pathogens have acid stress mechanisms that can help them adapt to varying $\mathrm{pH}$ environments [38,65-68]. Campylobacter jejuni has the gene make-up required to induce an acid-tolerance response [68]. In addition, there is an increase of acid tolerance in C. jejuni caused by coincubation with protozoa [69], and the genes involved in iron control and uptake are also induced $[67,68]$. We evaluated the interactions of six different OAs-propionic, L-lactic, formic, citric, butyric, and acetic-against 96 C. jejuni potential foodborne pathogen strains, while evaluating the effects that $\mathrm{pH}$ and the undissociated and dissociated $\mathrm{OA}$ species have on the bacteria at their OA $\mathrm{MIC}_{\mathrm{M}} \mathrm{s}$.

The central tendency of the MIC data show that median $\mathrm{MIC}_{\mathrm{M}}$ values for butyric, $\mathrm{L}$-lactic, and formic acid necessary for inhibition of the same strains have the highest values and the median acetic acid $\mathrm{MIC}_{\mathrm{M}}$ necessary for inhibition of the $C$. jejuni strains has an intermediate value, while the median $\mathrm{MIC}_{\mathrm{M}}$ values for inhibition by propionic and citric acid have the lowest values. However, L-lactic acid, followed by formic acid and acetic acid, have the highest ranges of $\mathrm{MIC}_{\mathrm{M}}$ values, and L-lactic acid and formic acid have the highest 90th percentile values, while citric acid has the lowest overall inhibition concentration $(10.66 \mathrm{mM})$. The citric acid 90th percentile value is the same value as was observed for citric acid in a previous study of $C$. coli [52]. It has previously been shown that citrate cannot be utilized by whole cells of Vibrio fetus (Campylobacter fetus) as an alternative energy source [70], nor by C. jejuni from swine [71]. Our data also suggests that citric acid is not utilized by C. jejuni, thereby making citric acid a good candidate to be used for disinfection of this bacterium.

\subsection{Differences in $p H$ Between Solutions of Different $O A$ s at the $M I C_{M}$}

Interestingly, it took a pH of 4.39 and 4.4 to inhibit $97 \%$ and $99 \%$ of the strains by L-lactic acid and formic acid, respectively, while it took a pH of $6.45,5.74,5.58$, and 5.18 to inhibit $97 \%, 99 \%, 99 \%$, and $99 \%$ of the strains by butyric, propionic, citric, and acetic acid, respectively. This is an average of $1.34 \mathrm{pH}$ unit difference between the $\mathrm{pH}$ necessary to inhibit $97-99 \%$ of the same 96 C. jejuni strains by these two groups of acids. We have reported $\mathrm{pH}$ differences at the $\mathrm{MIC}_{\mathrm{M}} \mathrm{s}$ of other Gram-negative strains against $\mathrm{OAs}$, and only one other bacterium had a greater $\mathrm{pH}$ difference between inhibition of all strains, C. coli with a $1.76 \mathrm{pH}$ unit difference [52]. The inhibition of $98 \%$ of 175 Pseudomonas aeruginosa strains by different OAs had a $0.98 \mathrm{pH}$ unit difference [72]. The inhibition of $98 \%$ of 344 E. coli O157:H7 strains had a $0.56 \mathrm{pH}$ unit difference between three different OAs [48], the inhibition of 138 non-O157 STEC strains had a $0.99 \mathrm{pH}$ unit difference between four different OAs [49], and inhibition of $95 \%$ of 145 Salmonella strains by four different OAs resulted in an observed $1.1 \mathrm{pH}$ unit difference [50]. These data demonstrate that inhibition of $C$. jejuni or the other Gram-negative bacteria previously studied are primarily not dependent on $\mathrm{pH}$, as others have suggested [40], but bacterial inhibition by OAs must be dependent on some other aspect of the OAs [52,73]. One might expect that the $\mathrm{MIC}_{\mathrm{M}} \mathrm{s}$ for the same bacteria against different $\mathrm{OAs}$ would be at the same $\mathrm{pH}$ value if $\mathrm{pH}$ were the primary cause of inhibition [52], but we did not observe that during experimentation.

\subsection{Relationships of $M I C_{M}$ Concentrations and $p H$ to the Undissociated OA Concentrations}

The inhibition of $100 \%$ of all 96 C. jejuni strains by the six undissociated OAs, propionic, L-lactic, formic, citric, butyric, and acetic acid required concentrations of $0.932 \mathrm{mM}$ citric acid to $51.71 \mathrm{mM}$ L-lactic acid, which is a difference in the level of undissociated acid of $50.78 \mathrm{mM}$ across all six OA species for inhibition of the same 96 strains. The MICs of most of the strains are observed at very dilute undissociated OA concentrations that approach 0.5 to $5 \mu \mathrm{M}$. No correlation was observed as to the concentration of undissociated OAs required to produce the $\mathrm{MIC}_{\mathrm{M}} \mathrm{s}$ for the $96 \mathrm{C}$. jejuni strains. These results agree with our earlier studies on other Gram-negative foodborne pathogens. Inhibition 
of $100 \%$ of $P$. aeruginosa (175 strains) by undissociated citric $(2.53 \mathrm{mM})$ or undissociated acetic acid $(21.65 \mathrm{mM})$ resulted in a difference of $\Delta=19.12 \mathrm{mM}$ OAs [72]. Inhibition of $98.3 \%$ of E. coli O157:H7 (344 strains) by undissociated citric $(2.86 \mathrm{mM})$ or undissociated acetic acid $(50.63 \mathrm{mM})$ was a difference of $\Delta=47.77 \mathrm{mM}$ OAs for disinfection of these strains [48]. Inhibition of $100 \%$ of non-O157 STEC (138 strains) by undissociated citric $(2.2 \mathrm{mM})$ and undissociated acetic acid $(49.11 \mathrm{mM})$ resulted in a difference of $\Delta=46.91 \mathrm{mM}$ OAs for disinfection of these strains [49]. Inhibition of $100 \%$ of Salmonella (145 strains) by undissociated citric $(2.29 \mathrm{mM})$ and undissociated acetic acid $(19.0 \mathrm{mM})$ resulted in a difference of $\Delta=16.71 \mathrm{mM}$ OAs for disinfection of these strains [50], and inhibition of C. coli (111 strains) by undissociated citric $(0.024 \mathrm{mM})$ or undissociated acetic acid $(39.93 \mathrm{mM})$ resulted in a difference of $\Delta=39.91 \mathrm{mM}$ [52]. In all five cases, the undissociated OA concentrations did not correlate with the $\mathrm{MIC}_{\mathrm{M}}$ s of the different bacteria. The levels of undissociated acids necessary to inhibit non-O157 STECs, E. coli O157:H7, C. coli, and in this study for C. jejuni were the highest, but most likely this increase was caused because of the glutamate and arginine-dependent acid-resistance systems [66] used to protect $E$. coli strains from extreme acid stress or the maintenance of iron homeostasis to protect against oxidative stress and acid resistance in Campylobacter spp. [74] and specifically C. jejuni [67,68], or bacteria utilization of OAs as an energy source.

The concentrations of undissociated OAs required to inhibit the 96 strains can be viewed from another perspective. Looking at the $\mathrm{pH}$ of the system at the points where the 96 strains are inhibited by the undissociated OA clearly shows that close to all 96 strains are inhibited by undissociated citric acid as the undissociated OA concentration approaches zero, and in fact, most of the strains are inhibited by all six organic acids as the undissociated OA concentrations approach zero. These results are not realistic, suggesting that the undissociated OAs play a small part, if any, in inhibiting C. jejuni.

\subsection{Relationships of $\mathrm{MIC}_{M}$ Concentrations and $\mathrm{pH}$ to the Dissociated OA Concentrations}

The inhibition of 96 C. jejuni strains by dissociated citric acid at $20.39 \mathrm{mM}$ and inhibition of $99 \%$ of the strains by propionic and acetic acid at 24.36 and $24.86 \mathrm{mM}$, respectively, and $97 \%$ of the strains by butyric acid at $22.72 \mathrm{mM}$ formed a narrow inhibition band with a $\Delta=4.47 \mathrm{mM}$. This small concentration range observed for inhibition of most of the strains (97-99\%) is very defined, unlike what was observed for the undissociated acids. However, the largeness of the C. jejuni inhibition concentration range against dissociated L-lactic and formic acid is most likely due to the bacterial utilization of these two acids. Formate is metabolized by the multi-subunit formate dehydrogenase (FDH) in C. jejuni [75], which exhibits a chemoattraction to and respiration of formate, compared with other OAs making formic acid a primary energy source [76,77]. Other OAs, like acetic [77,78], butyric [77,78], propionic [78], and L-lactic $[78,79]$ can also be utilized by C. jejuni as energy sources. Campylobacter jejuni utilization of L-lactate proceeds through two NAD-independent L-LDHs-a non-flavin iron-sulfur containing enzyme, and a flavin and iron-sulfur containing enzyme [79]. Therefore, dissociated L-lactic and formic acid may be expected to have a high C. jejuni inhibition concentration, as was seen in our experiments. However, it was determined that $C$. jejuni strains isolated from humans did not utilize propionic acid [80]. The susceptibility of $C$. jejuni to OAs has been investigated by several researchers showing inconsistent results $[22,31,38,80,81]$. Due to C. jejuni utilization of acetic, butyric, and propionic acids, our experimental results show increased concentrations of dissociated OAs widening the band of $C$. jejuni inhibition, but the high dependence of $C$. jejuni on formic and L-lactic acid for energy production skews the formic and L-lactic acid curves well beyond those for other OAs. This same dependence on formic acid for energy production was observed in studies with C. coli [52], and major utilization of L-lactic acid was observed in a study of P. aeruginosa strains [72]. However, a relatively small band $(\Delta=5.24 \mathrm{mM})$ of inhibition resulting from $100 \%$ of the strains by L-lactic acid and citric acid and 97-99\% of the strains by butyric acid, propionic acid, and acetic acid shows a well-correlated group of dissociated OAs that inhibit C. jejuni. Previous studies of P. aeruginosa strains resulted in inhibition of $98 \%$ of the 175 strains by dissociated citric acid $(10.24 \mathrm{mM})$ and dissociated acetic acid $(9.98 \mathrm{mM})$, resulting in a difference in dissociated OAs of only $\Delta=0.26 \mathrm{mM}$ [72]. Inhibition of $98.3 \%$ of E. coli 
O157:H7 (344 strains) by dissociated propionic $(13.82 \mathrm{mM})$ and L-lactic acid $(19.12 \mathrm{mM})$ had a difference of $\Delta=5.54 \mathrm{mM}$ [48]. In a study of 138 non-O157 STEC strains, inhibition of $100 \%$ of the strains was accomplished by dissociated L-lactic acid $(12.93 \mathrm{mM})$ and citric acid $(19.12 \mathrm{mM})$ having a difference of only $\Delta=6.19 \mathrm{mM}$ [49]. Inhibition of all 145 Salmonella strains by dissociated propionic $(13.67 \mathrm{mM})$ and citric acid (19.03 mM) had a small difference of $\Delta=5.36 \mathrm{mM}$ [50], and inhibition of 111 C. coli strains by dissociated butyric $(22.56 \mathrm{mM})$ and L-lactic acid $(21.17 \mathrm{mM})$ resulted in a very small difference of $\Delta=1.39 \mathrm{mM}$ [52]. However, citric acid was not utilized by C. coli [52,71] and inhibition of $100 \%$ of the 111 C. coli strains by dissociated citric acid occurred at $10.64 \mathrm{mM}$ [52]. It should be noted that 95 of 96 C. jejuni strains were inhibited by dissociated citric acid at $10.62 \mathrm{mM}$ in this study.

Alternatively, we can look at the $\mathrm{pH}$ vs. the dissociated OA concentrations at the $\mathrm{MIC}_{\mathrm{M}} \mathrm{s}$. The $\mathrm{pH}$ varies widely at the $C$. jejuni $\mathrm{MIC}_{\mathrm{M}}$ s against the dissociated $\mathrm{OAs}$, but dissociated citric acid, the only OA not utilized by $C$. jejuni as an energy source, inhibited $100 \%$ of the strains at a concentration of $20.39 \mathrm{mM}$. This dissociated OA value compares well with dissociated OA values obtained from previous studies of many other pathogens. Inhibition of $100 \%$ of Salmonella strains by all dissociated OAs tested required $\leq 19.03 \mathrm{mM}$ [50]; all VRE strains were inhibited by all dissociated OAs tested at $\leq 19.53 \mathrm{mM}$ [51]; all P. aeruginosa strains were inhibited by dissociated citric and acetic acid using a level of $\leq 18.79 \mathrm{mM}$ [72]; all non-O157 STEC strains were inhibited by all dissociated OAs tested at a level of $\leq 19.12 \mathrm{mM} \mathrm{[49];} \mathrm{all} \mathrm{C.} \mathrm{coli} \mathrm{strains} \mathrm{were} \mathrm{inhibited} \mathrm{by} \mathrm{dissociated} \mathrm{citric} \mathrm{acid} \mathrm{using} \mathrm{a} \mathrm{level}$ of $\leq 10.64 \mathrm{mM}$ [52]; and $98.3 \%$ of E. coli O157:H7 strains were inhibited by all OAs tested using a level of $\leq 19.36 \mathrm{mM}$ [48]. Approximately $20 \mathrm{mM}$ dissociated OA appears to be an optimum level for inhibition of the bacteria tested, unless the OA is utilized by the bacteria. The inhibition of $97-99 \%$ of the strains by dissociated propionic, acetic, and butyric acid are also utilized by $C$. jejuni required levels of $\leq 24.86 \mathrm{mM}[77,78]$, and have similar OA concentrations at the point of inhibition of the C. jejuni strains $(\Delta=2.14 \mathrm{mM})$. The inhibition of $97-99 \%$ of the strains by dissociated L-lactic acid and formic acid are utilized in a major way by $C$. jejuni required levels of $\leq 36.36 \mathrm{mM}$ to inhibit the $C$. jejuni strains. Unlike the undissociated OAs having a broad concentration pattern at the $\mathrm{MIC}_{\mathrm{M}} \mathrm{s}$ of the bacteria, the dissociated OAs have similar concentrations when inhibiting $97-100 \%$ of the 96 C. jejuni strains. The work described here is extremely promising, and provides insight into the mechanism of OA inhibition of bacteria, and also correlates well with our previous work on six other pathogenic bacteria. However, the studies described here were conducted in a laboratory setting under controlled conditions and controlled concentrations of bacteria as well as OAs, and further confirmation work in the field must be performed to confirm the results obtained in the laboratory.

\subsection{Mechanism by Which Organic Acids Control Bacteria Based on Our Studies}

The mechanism of OA bacterial inhibition has traditionally been assumed to be mainly dependent on $\mathrm{pH}$ [38] or the undissociated form of the OAs [39-44]. The activities of OAs change with $\mathrm{pH}$ levels, and the type and concentration of OA [47]; and OAs affect bacteria differently depending on whether the bacteria utilize the OA as an energy source [52]. An underlying premise of previous studies is that the OA must be protonated in order to pass through the outer membrane of the bacterial cell. Our present study with $C$. jejuni clearly shows that dissociated OA levels correlate best with the $\mathrm{MIC}_{\mathrm{M}} \mathrm{s}$ of $C$. jejuni, suggesting that the earlier premise followed by researchers might be wrong. Even though $C$. jejuni utilizes many of the OAs studied as energy sources, these dissociated OAs still correlate better with the $\mathrm{MIC}_{\mathrm{M}}$ s than either $\mathrm{pH}$ alone or the undissociated OAs. Almost all $96 \mathrm{C}$. jejuni strains $(97-100 \%)$ were inhibited by either dissociated citric, propionic, acetic, or butyric acid in the concentration range of 20.39-24.86 mM. Formic and lactic acid required much higher levels of dissociated OA for inhibition, most likely because these two OAs are well-utilized by C. jejuni as energy sources $[76,77,79]$. A previous publication states that "intracellular accumulation of anions is a primary contributor to inhibition of bacterial growth" [46], and our previous studies and these C. jejuni data fit well with that statement. Also, our previous work on six other pathogens, E. coli O157:H7 [48], non-O157 STECs [49], P. aeruginosa [72], Salmonella [50], VRE [51], and C. coli [52] correlates well with 
this current $C$. jejuni study. The first five bacterial pathogens required a dissociated OA concentration of $12.45-19.76 \mathrm{mM}$ for inhibition of nearly all strains tested, except for lactic acid which is utilized by $P$. aeruginosa as an energy source [72]. C. coli requires a dissociated OA concentration of from 10.64-22.56 $\mathrm{mM}$ for inhibition by the OAs not utilized as an energy source for C. coli [52]. Therefore, we have generated a large data pool that demonstrates bacterial inhibition by OAs is caused by a distinct concentration of the dissociated OA species, and the concentration is similar regardless of what OA is used, except for those OAs that are utilized by the bacteria as energy sources. In accordance with the Henderson-Hasselbalch equation, the $\mathrm{pH}, \mathrm{pK}_{\mathrm{a}}$, and the concentration of $\mathrm{OA}$ acid will specifically produce a concentration of dissociated OA species that inhibits bacteria. For the many pathogenic bacteria that we have studied, the general concentration range of dissociated OA species required to inhibit $97-100 \%$ of the bacteria is 20 to $25 \mathrm{mM}$.

\section{Conclusions}

In our study of $C$. jejuni inhibition by OAs, the inhibition of strains was associated with the concentration of dissociated propionic, citric, butyric, and acetic acid, and these OAs correlated with the $\mathrm{MIC}_{\mathrm{M}} \mathrm{s}$ of $97-100 \%$ of the C. jejuni strains tested. Bacterial inhibition was not dependent on $\mathrm{pH}$ or on the concentration of the undissociated OAs. Even though $C$. jejuni cannot utilize the citric acid cycle (CAC) to produce energy, $C$. jejuni can utilize some of the CAC intermediates and many OAs to produce energy: propionic, L-lactic, formic, butyric, and acetic acid can all be utilized by C. jejuni to produce energy, and L-lactic and formic acid are known to be good energy sources, while C. jejuni exhibits enhanced chemoattraction to formate in comparison to other OAs. This may account for the high concentrations of L-lactic and formic acid required to inhibit $C$. jejuni in our studies. Based on how well C. jejuni utilizes formate and L-lactate, the use of L-lactic and formic acid would most likely not be appropriate for disinfection or removal of this bacterium. The other OAs utilized by C. jejuni, acetic, butyric, and propionic acid, also would not be expected to be good for removing C. jejuni from carcasses, because these acids would have the tendency to revive the bacteria at reduced levels of dissociated acid. Dissociated citric acid showed good properties in our studies, inhibiting $100 \%$ of the C. jejuni strains at a reasonable concentration, and citric acid is not utilized by C. jejuni. A concentration of dissociated citric acid $(21 \mathrm{mM})$ could potentially be used to eliminate $C$. jejuni surface bacteria from animal carcasses. If the concentration of dissociated citric acid is reduced from the suggested $21 \mathrm{mM}$, then C. jejuni bacteria may escape disinfection. However, studies must be undertaken to confirm that the suggested concentrations of dissociated organic acids are adequate to remove $C$. jejuni bacteria in the field vs. the laboratory. If the dissociated OA used in a carcass wash is not controlled at the proper concentration, the wash may not provide the expected level of elimination of surface bacteria. Of the six OAs studied here, citric acid is the most efficient at inhibiting $C$. jejuni.

Author Contributions: Conceptualization, R.C.B.; Data curation, R.C.B.; Formal analysis, R.C.B.; Funding acquisition, D.J.N.; Methodology, R.C.B.; Project administration, J.A.B., R.C.A. and D.J.N.; Resources, D.C. and K.A.; Supervision, J.A.B., R.C.A. and D.J.N.; Validation, K.A.; Writing-original draft, R.C.B.; Writing一review \& editing, R.C.B., J.A.B., D.C., K.A., T.L.C. and R.C.A.

Funding: This study was funded by the United States Department of Agriculture, Agricultural Research Service.

Acknowledgments: Mention of trade names, proprietary products or specific equipment is solely for providing specific information and does not constitute a guarantee, warranty or endorsement by the U.S. Department of Agriculture and does not imply its approval to the exclusion of other products that may be suitable. Additionally, the views expressed in this article are those of the authors and do not necessarily reflect the official policy of the U.S. Department of Agriculture or the U.S. Government.

Conflicts of Interest: The authors declare no conflict of interest. 


\section{References}

1. Moore, J.E.; Corcoran, D.; Dooley, J.S.G.; Fanning, S.; Lucey, B.; Matsuda, M.; McDowell, D.A.; Mégraud, F.; Millar, B.C.; O'Mahony, R.; et al. Campylobacter. Vet. Res. 2005, 36, 351-382. [CrossRef]

2. Epps, S.V.R.; Harvey, R.B.; Hume, M.E.; Phillips, T.D.; Anderson, R.C.; Nisbet, D.J. Foodborne Campylobacter: Infections, metabolism, pathogenesis and reservoirs. Int. J. Environ. Res. Public Health 2013, 10, 6292-6304. [CrossRef]

3. Hofreuter, D. Defining the metabolic requirements for the growth and colonization capacity of Campylobacter jejuni. Cellul. Infect. Microbiol. 2014, 4, 137. [CrossRef]

4. Kaakoush, N.O.; Castaño-Rodríguez, N.; Mitchell, H.M.; Man, S.M. Global epidemiology of Campylobacter infection. Clin. Microbiol. Rev. 2015, 28, 687-720. [CrossRef]

5. European Food Safety Authority and European Centre for Disease Prevention and Control. The European Union summary report on trends and sources of zoonoses, zoonotic agents and food-borne outbreaks in 2015. EFSA J. 2016, 14, 4634.

6. World Health Organization (WHO). Campylobacter. Available online: https://www.who.int/news-room/factsheets/detail/campylobacter (accessed on 11 April 2019).

7. Penner, J.L. The Genus Campylobacter: A decade of progress. Clin. Microbiol. Rev. 1988, 1, 157-172. [CrossRef]

8. Blaser, M.J.; Taylor, D.N.; Feldman, R.A. Epidemiology of Campylobacter jejuni infections. Epidemiol. Rev. 1983, 5, 157-176. [CrossRef]

9. Centers for Disease Control and Prevention (CDC). Burden of foodborne illness: Findings. 2011. Available online: https://www.cdc.gov/foodborneburden/2011-foodborne-estimates.html (accessed on 13 April 2019).

10. Scallan, E.; Hoekstra, R.M.; Angulo, F.J.; Tauxe, R.V.; Widdowson, M.-A.; Roy, S.L.; Jones, J.L.; Briffin, P.M. Foodborne illness acquired in the United States-Major pathogens. Emerg. Infect. Dis. 2011, 17, 7-15. [CrossRef]

11. Nachamkin, I.; Szymanski, C.M.; Blaser, M.J. Campylobacter, 3rd ed.; ASM Press: Washington, DC, USA, 2008.

12. Baer, A.A.; Miller, M.J.; Dilger, A.C. Pathogens of interest to the pork industry: A review of research on interventions to assure food safety. Compr. Rev. Food Sci. F. 2013, 12, 183-217. [CrossRef]

13. Sifré, E.; Salha, B.A.; Ducournau, A.; Floch, P.; Chardon, H.; Mégraud, F.; Lehours, P. EUCAST recommendations for antimicrobial susceptibility testing applied to the three main Campylobacter species isolated in humans. J. Microbiol. Methods 2015, 119, 206-213. [CrossRef]

14. Roop, R.M., II; Smibert, R.M.; Johnson, J.L.; Krieg, N.R. Differential characteristics of catalase-positive campylobacters correlated with DNA homology groups. Can. J. Microbiol. 1984, 30, 938-951. [CrossRef]

15. Hébert, G.A.; Edmonds, P.; Brenner, D.J. DNA relatedness among strains of Campylobacter jejuni and Campylobacter coli with divergent serogroup and hippurate reactions. J. Clin. Microbiol. 1984, 20, 138-140.

16. Centers for Disease Control and Prevention (CDC). Campylobacter, Salmonella led bacterial foodborne illnesses in 2016. 2017. Available online: https://www.cdc.gov/media/releases/2017/p0420-campylobacter-salmonella. html (accessed on 15 April 2019).

17. Olson, C.K.; Ethelberg, S.; van Pelt, W.; Tauxe, R.V. Epidemiology of Campylobacter jejuni infections in industrialized nations. In Campylobacter, 3rd ed.; Nachamkin, I., Szymanski, C.M., Blaser, M.J., Eds.; ASM Press: Washington, DC, USA, 2008; pp. 163-189.

18. Kramer, J.M.; Frost, J.A.; Bolton, F.J.; Wareing, D.R. Campylobacter contamination of raw meat and poultry at retail sale: Identification of multiple types and comparison with isolates from human infection. J. Food Prot. 2000, 63, 1654-1659. [CrossRef]

19. Kapperud, G.; Espeland, G.; Wahl, E.; Walde, A.; Herikstad, H.; Gustavsen, S.; Tveit, I.; Natås, O.; Bevanger, L.; Digranes, A. Factors associated with increased and decreased risk of Campylobacter infection: A prospective case-control study in Norway. Am. J. Epidemiol. 2003, 158, 234-242. [CrossRef]

20. Humphrey, T.; Jørgensen, F. Pathogens on meat and infection in animals - Establishing a relationship using Campylobacter and Salmonella as examples. Meat Sci. 2006, 74, 89-97. [CrossRef]

21. Lindmark, H.; Boqvist, S.; Ljungström, M.; Ågren, P.; Björkholm, B.; Engstrand, L. Risk factors for campylobacteriosis: An epidemiological surveilance study of patients and retail poultry. J. Clin. Microbiol. 2009, 47, 2616-2619. [CrossRef]

22. Molatová, Z.; Skřivanová, E.; Macias, B.; McEwan, N.R.; Březina, P.; Marounek, M. Susceptibility of Campylobacter jejuni to organic acids and monoacylglycerols. Folia Microbiol. 2010, 55, 215-220. [CrossRef] 
23. Weinberger, M.; Moran-Gilad, J.; Rokney, A.; Davidov, Y.; Agmon, V.; Peretz, C.; Valinsky, L. Molecular epidemiology of Campylobacter jejuni infection in Israel-A nationwide study. Clin. Microbiol. Infect. 2016, 22, 1005.e9-1005.e15. [CrossRef]

24. Coker, A.O.; Isokpehi, R.D.; Thomas, B.N.; Amisu, K.O.; Obi, C.L. Human campylobacteriosis in developing countries. Emerg. Infect. Dis. 2002, 8, 237-243. [CrossRef]

25. Black, R.E.; Levine, M.M.; Clements, M.L.; Hughes, T.P.; Blaser, M.J. Experimental Campylobacter jejuni infection in humans. J. Infect. Dis. 1988, 157, 472-479. [CrossRef]

26. Kothary, M.H.; Babu, U.S. Infective dose of foodborne pathogens in volunteers: A review. J. Food Saf. 2001, 21, 49-73. [CrossRef]

27. Wachsmuth, I.K.; Sparling, P.H.; Barrett, T.J.; Potter, M.E. Enterohemorrhagic Escherichia coli in the United States. FEMS Immunol. Med. Microbiol. 1997, 18, 233-239. [CrossRef]

28. Keener, K.M.; Bashor, M.P.; Curtis, P.A.; Sheldon, B.W.; Kathariou, S. Comprehensive review of Campylobacter and poultry processing. Comp. Rev. Food Sci. Food Saf. 2004, 3, 105-116. [CrossRef]

29. Lee, M.D. Overview of avian Campylobacter infection, Merck Manual Veterinary Manual. Available online: https://merckvetmanual.com/poultry/avian-campylobacter-infection/overview-of-aviancampylobacter-infection (accessed on 15 April 2019).

30. Sahin, O.; Kassem, I.I.; Shen, Z.; Lin, J.; Rajashekara, G.; Zhang, Q. Campylobacter in poultry: Ecololgy and potential interventions. Avian Dis. 2015, 59, 185-200. [CrossRef]

31. Byrd, J.A.; Hargis, B.M.; Caldwell, D.J.; Bailey, R.H.; Herron, K.L.; McReynolds, J.L.; Brewer, R.L.; Anderson, R.C.; Bischoff, K.M.; Callaway, T.R.; et al. Effect of lactic acid administration in the drinking water during preslaughter feed withdrawal on Salmonella and Campylobacter contamination of broilers. Poult. Sci. 2001, 80, 278-283. [CrossRef]

32. Chaveerach, P.; Keuzenkamp, D.A.; Urlings, H.A.P.; Lipman, L.J.A.; van Knapen, F. In vitro study on the effect of organic acids on Campylobacter jejuni/coli populations in mixtures of water and feed. Poult. Sci. 2002, 81, 621-628. [CrossRef]

33. Chaveerach, P.; Keuzenkamp, D.A.; Lipman, L.J.A.; van Knapen, F. Effect of organic acids in drinking water for young broilers on Campylobacter infection, volatile fatty acid production, gut microflora and histological cell changes. Poult. Sci. 2004, 83, 330-334. [CrossRef]

34. Skånseng, B.; Kaldhusdal, M.; Moen, B.; Gjevre, A.-G.; Johannessen, G.S.; Sekelja, M.; Trosvik, P. Prevention of intestinal Campylobacter jejuni colonization in broilers by combinations of in-feed organic acids. J. Appl. Microbiol. 2010, 109, 1265-1273. [CrossRef]

35. Ghareeb, K.; Awad, W.A.; Mohnl, M.; Schatzmayr, G.; Böhm, J. Control strategies for Campylobacter infection in poultry production. Worlds Poult. Sci. J. 2013, 69, 57-76. [CrossRef]

36. Navarro, M.; Stanley, R.; Cusack, A.; Sultanbawa, Y. Combinations of plant-derived compounds against Campylobacter in vitro. J. Appl. Poult. Res. 2015, 24, 352-363. [CrossRef]

37. Birk, T.; Grønlund, A.C.; Christensen, B.B.; Knøchel, S.; Lohse, K.; Rosenquist, H. Effect of organic acids and marination ingredients on the survival of Campylobacter jejuni on meat. J. Food Protect. 2010, 73, 258-265. [CrossRef]

38. Ricke, S.C. Perspectives on the use of organic acids and short chain fatty acids as antimicrobials. Poult. Sci. 2003, 82, 632-639. [CrossRef] [PubMed]

39. Sofos, J.N.; Busta, F.F. Antimicrobial activity of sorbate. J. Food Protect. 1981, 44, 614-622. [CrossRef] [PubMed]

40. Blocher, J.C.; Busta, F.F.; Sofos, J.N. Influence of potassium sorbate and pH on ten strains of type A and B Clostridium botulinum. J. Food Sci. 1982, 47, 2028-2032. [CrossRef]

41. Ray, B.; Sandine, W.E. Acetic, propionic, and lactic acids of starter culture bacteria as biopreservatives. In Food Biopreservatives of Microbial Origin; Ray, B., Daeschel, M., Eds.; CRC Press, Inc.: Boca Raton, FL, USA, 1992; pp. 103-136.

42. Breidt, F., Jr.; Hayes, J.S.; McFeeters, R.F. Independent effects of acetic acid and pH on survival of Escherichia coli in simulated acidified pickle products. J. Food Protect. 2004, 67, 12-18. [CrossRef]

43. Leeson, S. Balancing science versus societal issues in poultry nutrition. CAB Rev. Perspect. Agric. Vet. Sci. Nutr. Nat. Resour. 2007, 2, 071. [CrossRef] 
44. Van Deun, K.; Haesebrouch, F.; Van Immerseel, F.; Ducatelle, R.; Pasmans, F. Short-chain fatty acids and L-lactate as feed additives to control Campylobacter jejuni infections in broilers. Avian Pathol. 2008, 37, 379-383. [CrossRef] [PubMed]

45. Presser, K.A.; Ross, T.; Ratkowsky, D.A. Modelling the growth limits (growth/no growth interface) of Escherichia coli as a function of temperature, $\mathrm{pH}$, lactic acid concentration, and water activity. Appl. Environ. Microbiol. 1998, 64, 1773-1779.

46. Carpenter, C.E.; Broadbent, J.R. External concentration of organic acid anions and pH: Key independent variables for studying how organic acids inhibit growth of bacteria in mildly acidic foods. J. Food Sci. 2009, 74, R12-R15. [CrossRef]

47. Bushell, F.M.L.; Tonner, P.D.; Jabbari, S.; Schmid, A.K.; Lund, P.A. Synergistic impacts of organic acids and $\mathrm{pH}$ on growth of Pseudomonas aeruginosa: A comparison of parametric and Bayesian non-parametric methods to model growth. Front. Microbiol. 2019, 9, 1-14. [CrossRef]

48. Beier, R.C.; Poole, T.L.; Brichta-Harhay, D.M.; Anderson, R.C.; Bischoff, K.M.; Hernandez, C.A.; Bono, J.L.; Arthur, T.M.; Nagaraja, T.G.; Crippen, T.L.; et al. Disinfectant and antibiotic susceptibility profiles of Escherichia coli O157:H7 strains from cattle carcasses, feces, and hides and ground beef from the United States. J. Food Protect. 2013, 76, 6-17. [CrossRef] [PubMed]

49. Beier, R.C.; Franz, E.; Bono, J.L.; Mandrell, R.E.; Fratamico, P.M.; Callaway, T.R.; Andrews, K.; Poole, T.L.; Crippen, T.L.; Sheffield, C.L.; et al. Disinfectant and antimicrobial susceptibility profiles of the big six non-O157 Shiga toxin-producing Escherichia coli strains from food animals and humans. J. Food Protect. 2016, 79, 1355-1370. [CrossRef] [PubMed]

50. Beier, R.C.; Callaway, T.R.; Andrews, K.; Poole, T.L.; Crippen, T.L.; Anderson, R.C.; Nisbet, D.J. Interactions of organic acids with Salmonella strains from feedlot water-sprinkled cattle. J. Food Chem. Nanotechnol. 2017, 3, 60-66. [CrossRef]

51. Beier, R.C.; Harvey, R.B.; Poole, T.L.; Hume, M.E.; Crippen, T.L.; Highfield, L.D.; Alali, W.Q.; Andrews, K.; Anderson, R.C.; Nisbet, D.J. Interactions of organic acids with vancomycin-resistant Enterococcus faecium isolated from community wastewater in Texas. J. Appl. Microbiol. 2018, 126, 480-488. [CrossRef] [PubMed]

52. Beier, R.C.; Harvey, R.B.; Hernandez, C.A.; Hume, M.E.; Andrews, K.; Droleskey, R.E.; Davidson, M.K.; Bodeis-Jones, S.; Young, S.; Duke, S.E.; et al. Interactions of organic acids with Campylobacter coli from swine. PLoS ONE 2018, 13, e0202100. [CrossRef]

53. Alakomi, H.-L.; Skyttä, E.; Saarela, M.; Mattila-Sandholm, T.; Latva-Kala, K.; Helander, I.M. Lactic acid permeabilizes Gram-negative bacteria by disrupting the outer membrane. Appl. Environ. Microbiol. 2000, 66, 2001-2005. [CrossRef]

54. Stern, N.J.; Wojton, B.; Kwiatek, K. A differential-selective medium and dry ice-generated atmosphere for recovery of Campylobacter jejuni. J. Food Protect. 1992, 55, 514-517. [CrossRef]

55. Clinical and Laboratory Standards Institute (CLSI). Methods for Dilution Antimicrobial Dilution and Disk Susceptibility Testing of Infrequently Isolated or Fastidious Bacteria; Approved Guideline-2nd ed.; Clinical and Laboratory Standards Institute: Wayne, PA, USA, 2010; M45-A2; Volume 30, No 18.

56. TREK Diagnostic Systems. TREK materials and methods for sensititre susceptibility plates for Campylobacter. Available online: http://www.uniscience.co.kr/data/trds/sensi_manuals/Campylobacter_panel.pdf (accessed on 18 April 2019).

57. Andrews, J.M. Determination of minimum inhibitory concentrations. J. Antimicrob. Chemother. 2001, 48, 5-16. [CrossRef]

58. Beier, R.C.; Bischoff, K.M.; Ziprin, R.L.; Poole, T.L.; Nisbet, D.J. Chlorhexidine susceptibility, virulence factors, and antibiotic resistance of beta-hemolytic Escherichia coli isolated from neonatal swine with diarrhea. Bull. Environ. Contam. Toxicol. 2005, 75, 835-844. [CrossRef]

59. Beier, R.C.; Duke, S.E.; Ziprin, R.L.; Harvey, R.B.; Hume, M.E.; Poole, T.L.; Scott, H.M.; Highfield, L.D.; Alali, W.Q.; Andrews, K.; et al. Antibiotic and disinfectant susceptibility profiles of vancomycin-resistant Enterococcus faecium (VRE) isolated from community wastewater in Texas. Bull. Environ. Contam. Toxicol. 2008, 80, 188-194. [CrossRef]

60. Beier, R.C.; Anderson, P.N.; Hume, M.E.; Poole, T.L.; Duke, S.E.; Crippen, T.L.; Sheffield, C.L.; Caldwell, D.J.; Byrd, J.A.; Anderson, R.C.; et al. Characterization of Salmonella enterica isolates from turkeys in commercial processing plants for resistance to antibiotics, disinfectants, and a growth promoter. Foodborne Pathog. Dis. 2011, 8, 593-600. [CrossRef] [PubMed] 
61. Beier, R.C.; Callaway, T.R.; Andrews, K.; Poole, T.L.; Crippen, T.L.; Anderson, R.C.; Nisbet, D.J. Disinfectant and antimicrobial susceptibility profiles of Salmonella strains from feedlot water-sprinkled cattle: Hides and feces. J. Food Chem. Nanotechnol. 2017, 3, 50-59. [CrossRef]

62. Helmenstine, A.M. Henderson-Hasselbalch Equation and Example. 2014. Available online: http://chemistry. about.com/od/acidsbase1/a/hendersonhasselbalch.htm (accessed on 22 April 2019).

63. Shaheen, B.W.; Miller, M.E.; Oyarzabal, O.A. In vitro survival at low $\mathrm{pH}$ and acid adaptation response of Campylobacter jejuni and Campylobacter coli. J. Food Saf. 2007, 27, 326-343. [CrossRef]

64. Lund, P.; Tramonti, A.; De Biase, D. Coping with low pH: Molecular strategies in neutralophilic bacteria. FEMS Microbiol. Rev. 2014, 38, 1091-1125. [CrossRef] [PubMed]

65. Reid, A.N.; Pandey, R.; Palyada, K.; Naikare, H.; Stintzi, A. Identification of Campylobacter jejuni genes involved in the response to acidic $\mathrm{pH}$ and stomach transit. Appl. Environ. Microbiol. 2008, 74, 1583-1597. [CrossRef] [PubMed]

66. Bearson, B.L.; Lee, I.S.; Casey, T.A. Escherichia coli O157:H7 glutamate- and arginine-dependent acid-resistance systems protect against oxidative stress during extreme acid challenge. Microbiology 2009, 155, 805-812. [CrossRef]

67. Birk, T.; Wik, M.T.; Lametsch, R.; Knøchel, S. Acid stress response and protein induction in Campylobacter jejuni isolates with different acid tolerance. BMC Microbiol. 2012, 12, 174. [CrossRef]

68. Varsaki, A.; Murphy, C.; Barczynska, A.; Jordan, K.; Carroll, C. The acid adaptive tolerance response in Campylobacter jejuni induces a global response, as suggested by proteomics and microarrays. Microb. Biotechnol. 2015, 8, 974-988. [CrossRef]

69. Axelsson-Olsson, D.; Svensson, L.; Olofsson, J.; Salomon, P.; Waldenström, J.; Ellström, P.; Olsen, B. Increase in acid tolerance of Campylobacter jejuni through coincubation with amoebae. Appl. Environ. Microbiol. 2010, 76, 4194-4200. [CrossRef]

70. Kiggins, E.M.; Plastridge, W.N. Some metabolic activities of Vibrio fetus of bovine origin. J. Bacteriol. 1958, 75, 205-208.

71. Elharrif, Z.; Mégraud, F. Characterization of thermophilic Campylobacter. I. Carbon-substrate utilization tests. Curr. Microbiol. 1986, 13, 117-122. [CrossRef]

72. Beier, R.C.; Foley, S.L.; Davidson, M.K.; White, D.G.; McDermott, P.F.; Bodeis-Jones, S.; Zhao, S.; Andrews, K.; Crippen, T.L.; Sheffield, C.L.; et al. Characterization of antibiotic and disinfectant susceptibility profiles among Pseudomonas aeruginosa veterinary isolates recovered during 1994-2003. J. Appl. Microbiol. 2014, 118, 326-342. [CrossRef] [PubMed]

73. Hirshfield, I.N.; Terzulli, S.; O’Byrne, C. Weak organic acids: A panoply of effects on bacteria. Sci. Prog. 2003, 86, 245-269. [CrossRef] [PubMed]

74. van Vliet, A.H.M.; Ketley, J.M.; Park, S.F.; Penn, C.W. The role of iron in Campylobacter gene regulation, metabolism and oxidative stress defense. FEMS Microbiol. Rev. 2002, 26, 173-186. [CrossRef] [PubMed]

75. Shaw, F.L.; Mulholland, F.; Le Gall, G.; Porcelli, I.; Hart, D.J.; Pearson, B.M.; van Vliet, A.H.M. Selenium-dependent biogenesis of formate dehydrogenase in Campylobacter jejuni is controlled by the fdhTU accessory genes. J. Bacteriol. 2012, 194, 3814-3823. [CrossRef] [PubMed]

76. Kassem, I.I.; Candelero-Rueda, R.A.; Esseili, K.A.; Rajashekara, G. Formate simultaneously reduces oxidase activity and enhances respiration in Campylobacter jejuni. Sci. Rep. (Nat.) 2017, 6, 40117. [CrossRef] [PubMed]

77. Wright, J.A.; Grant, A.J.; Hurd, D.; Harrison, M.; Guccione, E.J.; Kelly, D.J.; Maskell, D.J. Metabolite and transcriptome analysis of Campylobacter jejuni in vitro growth reveals a stationary-phase physiological switch. Microbiology 2009, 155, 80-94. [CrossRef]

78. Luethy, P.M.; Huynh, S.; Ribardo, D.A.; Winter, S.E.; Parker, C.T.; Hendrixson, D.R. Microbiota-derived short-chain fatty acids modulate expression of Campylobacter jejuni determinants required for commensalism and virulence. mBio 2017, 8, e00407-e00417. [CrossRef]

79. Thomas, M.T.; Shepherd, M.; Poole, R.K.; van Vliet, A.H.M.; Kelly, D.J.; Pearson, B.M. Two respiratory enzyme systems in Campylobacter jejuni NCTC 11168 contribute to growth on L-lactate. Environ. Microbiol. 2011, 13, 48-61. [CrossRef] 
80. Wagley, S.; Newcombe, J.; Laing, E.; Yusul, E.; Sambles, C.M.; Studholme, D.J.; La Ragione, R.M.; Titball, R.W.; Champion, O.L. Differences in carbon source utilisation distinguish Campylobacter jejuni from Campylobacter coli. BMC Microbiol. 2014, 14, 262. [CrossRef]

81. Shin, S.-Y.; Hwang, H.-J.; Kim, W.J. Inhibition of Campylobacter jejuni in chicken by ethanol, hydrogen peroxide, and organic acids. J. Microbiol. Biotechnol. 2001, 11, 418-422. 